\title{
Contamination control of microbe Ziziphus spina [christti] seed in vitro culture
}

\author{
Elahe Ahmadi · Seyed Mohammad Hosseini Nasr • \\ Hamid Jalilvand · Sekineh Kiani Savadkoohi
}

Received: 20 April 2011 /Revised: 14 February 2012/Accepted: 20 February 2012/Published online: 6 March 2012

(C) The Author(s) 2012. This article is published with open access at Springerlink.com

\begin{abstract}
Ziziphus spina [christti] is a naturally distributed tree in subtropical, arid and semi-arid parts of Iran. It is ecologically and economically important due to its tolerance to drought and salinity. Most tree seeds are infected with parasitic and saprophytic microorganisms which decrease the seed germination and seedling establishment. The goal of this paper was to evaluate the ability of selected chemical solutions to inhibit the growth of variety of microbial contaminants in Z. spina [christti] seeds and to enhance the seed germination. Different chemical treatments were used in surface sterilization of seeds: (Treatment 1 ) sodium hypochlorite $(\mathrm{NaOCl})$ in concentrations of 1, 2 and $4 \%$ for $20 \mathrm{~min}$. (Treatment 2 ) hydrogen peroxide $\left(\mathrm{H}_{2} \mathrm{O}_{2}\right)$ in concentration of $4,8,12 \%$ treated for $10 \mathrm{~min}$. (Treatment 3) $1 \%$ mercuric chloride $\left(\mathrm{HgCl}_{2}\right)$ at duration 10, 15, 20, $25 \mathrm{~min}$. Seeds were scarified and aseptically, planted on agar Murashige and Skoog (MS) medium. Contaminants were identified according to their morphological and cultural characteristics. Bacterial contaminants included Xanthomonas sp. While Fungal isolates were Fusarium, Penicillium, Alternaria, Rhizopus, and Aspergillus. Our experiment reveals that $4 \% \mathrm{NaOCl}$ followed by benomyl is the best sterilization treatment for Z $Z$ spina [christti] seeds, since the highest number of germination
\end{abstract}

Communicated by T. Koike.

E. Ahmadi $(\varangle)$ - S. M. H. Nasr · H. Jalilvand

Department of Forestry, Faculty of Natural Resources,

Sari Agricultural Science and Natural Resources University,

Sari, Iran

e-mail: ahmadi_silva@yahoo.com

S. K. Savadkoohi

Faculty of Natural Resources, Mazandaran University, Sari, Iran and highest number of sterilized seeds was observed after this treatment.

Keywords Microbial contamination - Surface sterilization - Chemical solution - Ziziphus spina [christti]

\section{Introduction}

The genus Ziziphus belongs to the family Rhamnaceae, consisting of about 100 deciduous or evergreen tree and shrub species distributed in the tropical and subtropical regions (Dweck 2005). Ziziphus spina [christti] (L.) Willd is a species distributed in the West Africa to North East Africa, Ethiopia and Eastern Africa, especially in the drier tropical areas. It is wild in the Middle East (especially Iran), Saudi Arabia and also farther west in Turkey (AzamAli et al. 2006). The species is ecologically and economically important due to its tolerance to drought and salinity besides the high value of non-woody products; nutritious fruit and leaves and shoots as a source of saponins and tannin (Al-Sulaiman and Barakat 2010). It is suitable for re-vegetation of degraded lands, but little is known about the physiology of seed germination and seedling establishment (Sohail et al. 2009). All the parts of the plant are used in folklore medicine for the curing of various diseases (Motamedi et al. 2009). In a study conducted by Farrar et al. (2008) during 2001-2007 at different areas in South Iran, they showed that there were 28 insects and 3 mites that damaged different parts of $Z$. spina [christti] trees. Tree, leaves, spines, seeds and fruits of the Z. spina [christti] are shown in Fig. 1. Since Ziziphus spina [christti] is a cross-pollinated plant, a wide range of genetic variability exists in the nature. Vegetative propagation, particularly in vitro propagation, assumes importance for mass 
and clonal propagation (Assareh and Sardabi 2005). Since seeds of $Z$. spina [christti] require scarification treatments to germinate (Moustafa et al. 1998), vegetative propagation plays a significant role in its improvement in breeding programs. However, in vitro Ziziphus seed germination; low multiplication rates and high contamination in the seeds are some of the difficulties in Ziziphus micropropagation. In vitro contamination by fungi, bacteria, or yeast is one of the most serious problems of commercial and research plant tissue culture laboratories. The inability to control contamination levels adequately is the primary reason for failures in commercial laboratories (Niedz and Bausher 2002). The establishment of an in vitro culture requires the removal of fungal and bacterial contaminants in the planting material. Some previous studies have shown that sodium hypochlorite solution at different concentrations was effective in seed disinfection of various species. Do Rego et al. (2009) showed that a $0.5 \%$ sodium hypochlorite solution was effective in Cereus jamacaru seed disinfestation. De Moraes et al. (2010) found that the disinfection of artichoke seeds can be done by immersing them in $70 \%$ alcohol for 30 min followed by immersion in $2 \%$ active chlorine solution for $10 \mathrm{~min}$, before removing the tegument. Oyebanji et al. (2009) showed that a treatment with locally produced bleaching solution, containing $3.5 \%$ sodium hypochlorite for $20-45$ min could be used to surface sterilize cowpea, rice and sorghum seeds for seed culture. Golle et al. (2010) found that the best disinfection treatment for Pinus taeda seeds was $30 \mathrm{~s}$ in $70 \%$ etha$\mathrm{nol}+5 \mathrm{~min}$ in $3 \%$ sodium hypochlorite treatment. Ksenija and Dragana (2005) carried out the experiments to investigate the infection of fungi or bacteria on seeds at germination and hypocotyls and growth in sunflower. The best way to control fungi or bacteria according to their results was the combination of 5\% commercial bleach for $60 \mathrm{~min}$ and dry heating at $45^{\circ} \mathrm{C}$ for $60 \mathrm{~min}$. According to the scientific literature, the most effective treatment against fungal contaminations was benomyl treatment. Altan et al. (2010) showed that the benomyl $\left(100 \mathrm{mg} \mathrm{dm}^{-3}\right)+$ nystatin $\left(100 \mathrm{mg} \mathrm{dm}^{-3}\right)$ treatment combination was the most effective treatment against fungal contaminants. Similar results were obtained by Barnett and McGilvary (2001) and Allen et al. (2004). Barnett and Varela (2004) tested many chemicals to reduce large populations of microorganisms on longleaf pine (Pinus palustris). However, hydrogen peroxide, thiophanate methyl, and thiram provided the best amount of disinfection. Numerous techniques have been examined with varying degrees of success for increasing seed germination and eliminating contaminations of microbial and other seed borne fungi. These treatments included fungicides (Runion and Bruck 1988), surface sterilization agents (Barnett 1976; Wenny and Dumroese
1987) and hot water and microwave treatments (James et al. 1988).

Seed treatments to control seed borne inoculums can be based on the chemical, physical, mechanical, and biological practices (Fraedrich 1996). Chemical and physical methods are primary considerations for quarantine issues. Chemical seed treatments (like the application of fungicides) have been used routinely to control seed borne pathogens and are often the cheapest and most effective means for control. Fungicides are used to kill or to inhibit growth of seed borne fungi and can be systemic or nonsystemic in their action (Allen et al. 2004). Highly selective systemic fungicides have proved to be most useful for the eradication of inoculum in seeds. Techniques for the infusion of fungicides into seeds have been developed for numerous agricultural crops (Fraedrich 1996), but experiences with seeds of forest tree species are limited. Fungicides, such as benomyl and thiobendazole have been used to control seed borne pathogens on conifers with mixed results. Disinfectants, such as sodium hypochlorite and hydrogen peroxide have proved useful for elimination of inoculum associated with the seed coats of conifer species (Allen et al. 2004). Combining this practice with the use of selective fungicides may provide effective control of pathogens internally and externally on forest tree seeds. This study was undertaken to evaluate the effect of fungicide and other chemical solutions on sterilizing of Ziziphus seeds. We used benomyl to enhance germination and hydrogen peroxide, sodium hypochlorite and mercuric chloride as seed disinfectants. The aim of this experiment was removal of contamination of Ziziphus seed under laboratory conditions and producing plants free of pathogens from seeds by the application of a simple, efficient and economical method in which we could obtain results in short time. Seeds free of contamination and also healthy plants free of pathogens could be applied in natural field and extension of this species.

\section{Materials and methods}

Collection and identification of plant material

Ziziphus spina [christti] seeds were collected from research institute of forests and rangelands, Ahwaz, Iran in 2010. The laboratory tests were conducted at the tissue culture laboratory at Department of Forestry, Faculty of Natural Resources, Sari Agricultural Science and tissue culture laboratory at Natural Resources University, Sari, Iran. Murashinge and Skoog (1962) agar medium was used as the tissue culture medium and sterilization of the medium was done by autoclaving at $121^{\circ} \mathrm{C}$ for $20 \mathrm{~min}$. 


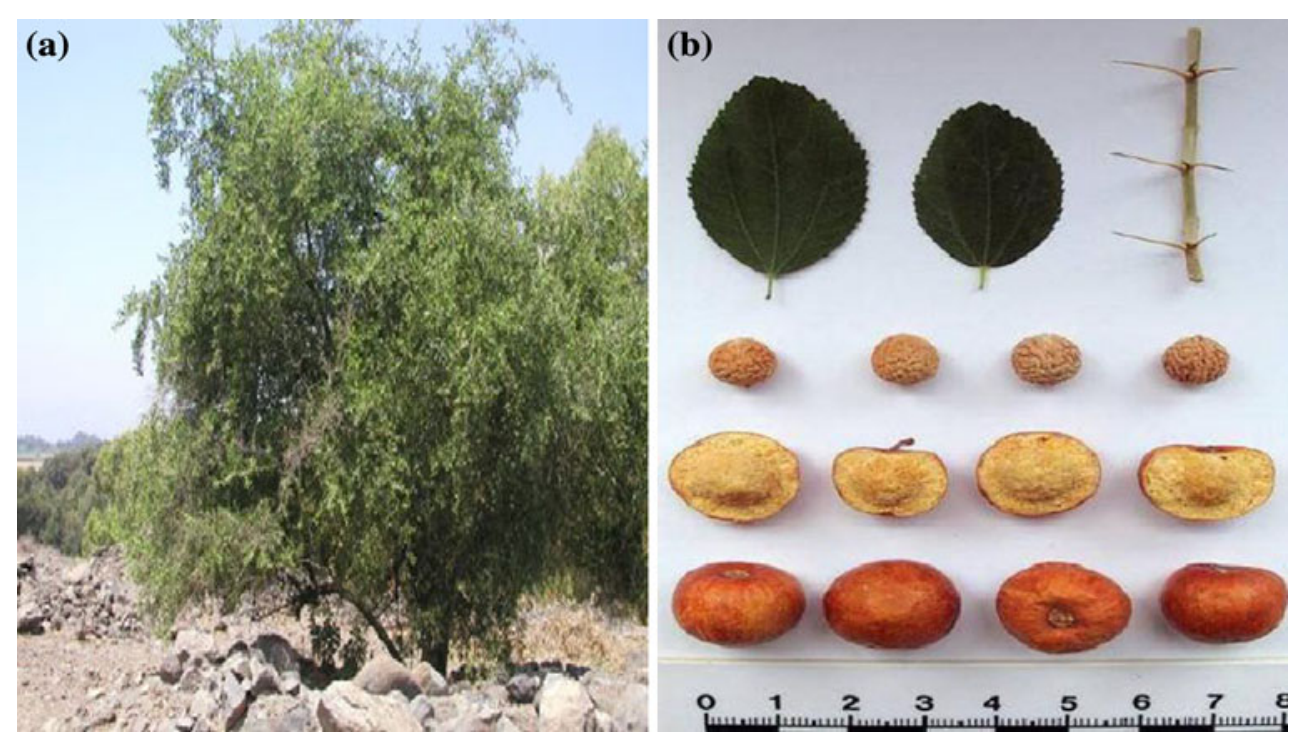

Fig. 1 Physiognomy of the tree (a) and morphology of leaves, spines, seeds and fruits (b) of Ziziphus spina [christti]. Scale (cm)

\section{Sterilization and incubation of plant cultures}

The seeds were surface sterilized by rinsing with tap water and then dipping them in $0.1 \% \mathrm{HgCl}_{2}$ solution for $15 \mathrm{~min}$. The seeds were dipped in $70 \%$ ethanol for $40 \mathrm{~s}$ followed by thorough rinsing in sterile distilled water. The excised seeds were then aseptically transferred to the culture medium, labeled and incubated at $23 \pm 1^{\circ} \mathrm{C}$ during the day and $19 \pm 1^{\circ} \mathrm{C}$ at night for 3 weeks.

Laboratory analysis of isolation of microbial contaminants

From the contaminated plant seed culture tubes, emerging microbes were isolated by inoculating them on acidified potato dextrose agar (APDA) and incubated for 6 days at $26^{\circ} \mathrm{C}$ under $12 \mathrm{~h}$ photoperiod in the case of fungi and on nutrient agar incubated for 3 days at $30^{\circ} \mathrm{C}$ under $12 \mathrm{~h}$ photoperiod. Pure isolates obtained from repeated subculturing of the isolates were placed in an agar slant in McCartney bottles and stored at $4^{\circ} \mathrm{C}$ in a refrigerator.

\section{Characterization and identification of isolates}

The fungal isolates were identified using cultural characters and morphology by comparison with standard descriptions (Barnett and Hunter 1972). In case of bacteria, beside the morphological characteristics, a number of biochemical and physiological tests were carried out on the isolates. The biochemical tests includes Gram staining, spore staining, motility test, catalase production, oxidase test, indole production, citrate utilization, urease activity, hydrogen sulfide production, gelatin hydrolysis, starch hydrolysis and carbohydrate utilization.

Effect of different treatments on seed sterilization and seed germination

Different surface sterilization treatments included: (T1) sodium hypochlorite $(\mathrm{NaOCl})$ in concentrations of 1,2 , $4 \%$ for $20 \mathrm{~min}$, (T2) hydrogen peroxide $\left(\mathrm{H}_{2} \mathrm{O}_{2}\right)$ in concentration of $4,8,12 \%$ for $10 \mathrm{~min}$, (T3) $1 \%$ mercuric chloride $\left(\mathrm{HgCl}_{2}\right)$ for $10,15,20$ or $25 \mathrm{~min}$. Seeds were scarified with sulfuric acid $98 \%$ for $4 \mathrm{~h}$ and then washed thoroughly with tap water and distilled water and then immersed in the above-mentioned solutions and then dipped seeds in $2 \%$ benomyl for 5 min and rinsed with distilled water. Finally, seeds were dipped in $70 \%$ ethanol for $90 \mathrm{~s}$ followed by thorough rinsing in sterile distilled water. The seeds were aseptically planted on agar-solidified Murashige and Skoog (MS) (1962) in culture tubes $(25 \mathrm{~mm} \times 200 \mathrm{~mm})$ containing cotton plugs. The cultures were incubated under 1,000 lux light intensity provided by white fluorescent lamps at $27^{\circ} \mathrm{C}$. Number of germinated seeds and number of uninfected seeds (sterilized seeds) in each tube was observed weekly for calculation and statistically analyzed. Final germination percentage (FG) and sterilization of seed (S) was calculated (Panwar and Bhardwaj 2005).

$\mathrm{FG}=n / N \times 100$

$S=n / N \times 100$

where $n$ are the number of germinated seeds or $n$ number of uninfected of seed, $N$ is the total number of seeds. 
Statistical analysis

A randomized complete design was used with five replications and five seeds in each replicate. Data were statistically analyzed in SPSS program. Duncan's test $(p<0.05)$ was used to compare means within and among treatments.

\section{Results}

Microbial contaminants of identification of isolates

Four microbial contaminants ( 1 bacteria and 3 fungi) were found associated with the seed cultures. The bacterial contaminant was Xanthomonas sp., while fungal isolates were Fusarium, Penicillium, Alternaria, Rhizopus, and Aspergillus. The rate of occurrence of bacteria was higher than that of fungi in the plant tissue cultures.

Effect of chemical treatments on seed germination and seed sterilization

The present study clearly demonstrated significant differences in seed germination and sterilization percentages were observed among different chemical treatments $(p<0.0001)$. Both the duration of the treatment, chemicals used and their strength affected the seed germination $(F=77.75, p<0.001$ and $F=64.57, p<0.001)$ and sterilization $(F=34.15, \quad p<0.0001$ and $F=13.42$, $p<0.001)$ significantly. However, the mean total number of sterilized seed parameter was not affected significantly by the interaction between time and sterile treatment. Figure 2 presents the maximum effect of sterilization and germination of seeds by $4 \% \mathrm{NaOCl}$ and inadequate ability of $\mathrm{H}_{2} \mathrm{O}_{2}$ for controlling the contamination and germination.

Effect of chemical treatments and time factors on germination parameters

Mean final germination in interaction between time and sterile treatment in $\mathrm{NaOCl} 4 \%, \mathrm{NaOCl} 2 \%$ solution and third, fourth and fifth weeks and $\mathrm{HgCl}_{2} 10 \mathrm{~min}$ in fifth week were significantly higher when compared with those of other treatments. $\mathrm{NaOCl} 1 \%, \mathrm{H}_{2} \mathrm{O}_{2} 12 \%, \mathrm{HgCl}_{2} 15 \mathrm{~min}$, $\mathrm{HgCl}_{2} 20$ min solution in first week and $\mathrm{H}_{2} \mathrm{O}_{2} 8 \%$ in first, second and third week and $\mathrm{H}_{2} \mathrm{O}_{2} 4 \%$ solution in all 4 weeks revealed the lowest treatments in final germination. $\mathrm{HgCl}_{2} 25 \mathrm{~min}, 20 \mathrm{~min}$ treatment in third, fourth and fifth weeks was more than that of this treatments. Final germination parameter in $\mathrm{NaOCl} 4 \%$ treatment was significantly greater than that of other treatments and the maximum final germination was recorded in this treatments. This treatment was followed by $\mathrm{HgCl}_{2} 20 \mathrm{~min}$ and 10 min and $\mathrm{NaOCl} 2 \%$ treatments. $\mathrm{H}_{2} \mathrm{O}_{2} 4 \%$ and $\mathrm{H}_{2} \mathrm{O}_{2} 8 \%$ solution treatments recorded the lowest germination parameter as compared to other treatments in final germination.

\section{Effect of germination}

Sterilization percentage of seeds in $\mathrm{NaOCl} 4 \%, \mathrm{HgCl}_{2} 15$, 20 and 25 min treatments were significantly greater than that of other treatments. $\mathrm{H}_{2} \mathrm{O}_{2} 4 \%, \mathrm{H}_{2} \mathrm{O}_{2} 8 \%$ solutions were the least effective treatments for sterilizing seeds. Other treatments could be almost placed in a similar means range (Fig. 3).

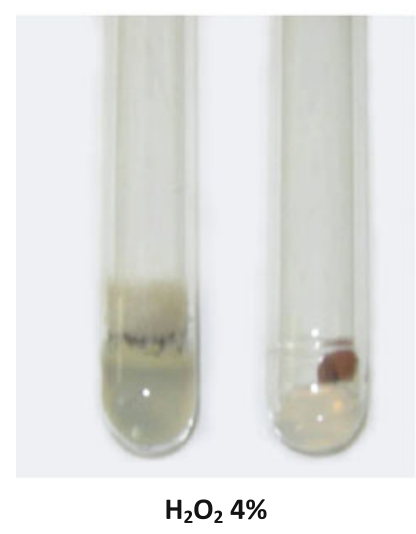

(a)

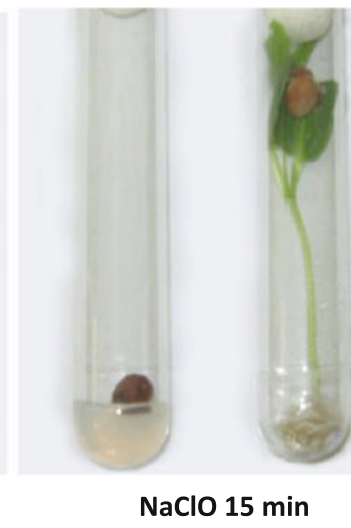

(b)

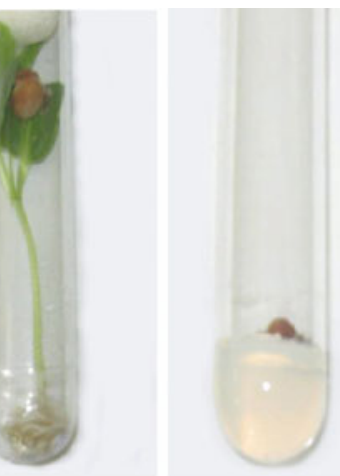

$\mathrm{HgCl}_{2}$

(c)
Fig. 2 Effect of treatments on germination and sterilization of seeds (correct $\mathrm{NaClO}$ and $\mathrm{HgCl}_{2}$ in legends to figure) a Germination of the seeds sterilized and plants free of microbial contamination by $4 \%$ $\mathrm{NaOCl}+$ benomyl (right tube). Seeds sterilized by $4 \% \mathrm{NaO}-$ $\mathrm{Cl}+$ benomyl (left tube). b Germination of the seeds sterilized and plants free of microbial contamination by $\mathrm{HgCl}_{2} 15$ min + benomyl (right tube). Seeds sterilized by $\mathrm{HgCl}_{2} 15 \mathrm{~min}+$ benomyl (left tube). c Seeds sterilized by $4 \% \mathrm{H}_{2} \mathrm{O}_{2}+$ benomyl (right tube) inadequate ability of $\mathrm{H}_{2} \mathrm{O}_{2}+$ benomyl for controlling the contamination and germination 


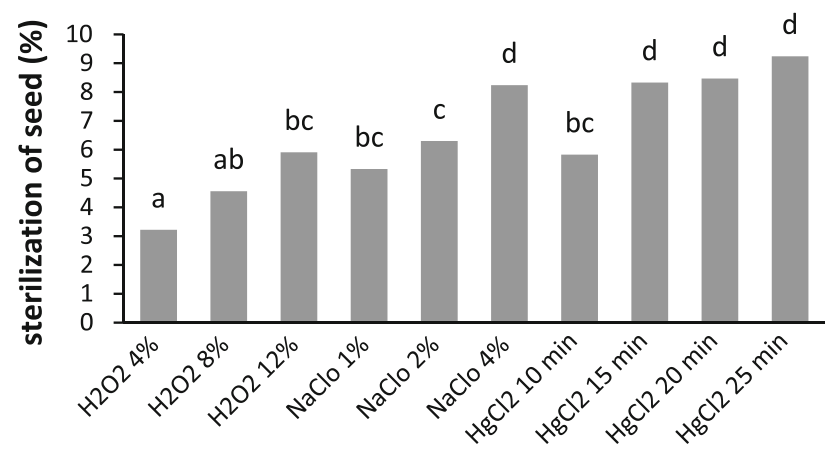

Fig. 3 Comparison of means obtained for parameters on sterilization of seeds parameter in different sterilization treatments $\left(\mathrm{H}_{2} \mathrm{O}_{2} 4,8\right.$, $12 \% ; \mathrm{NaOCl} 1,2,4 \% ; \mathrm{HgCl}_{2} 10,15,20,25 \mathrm{~min}$ )

\section{Discussion}

Seed germination failure in Ziziphus was observed in our study to be due to seed pathogenic bacteria and fungi. Since permanent treatment of seed is the most expensive and time-consuming method, we have used surface sterilization. Surface sterilization can be performed by exposure of seeds to UV light, heat or to chemicals. However, UV irradiation can damage DNA and heat can induce death of embryo. Thus, we tried to develop sterilization technique using chemical solutions. In the current study, benomyl showed some efficacy against fungi in Ziziphus seed. Barnett et al. (1999) and Runion and Bruck (1988) have shown that benomyl and thiabendazole improved germination of longleaf pine seed in previous studies. Based on the obtained data, germination of Ziziphus seeds was significantly lower after sterilization by $4 \% \mathrm{H}_{2} \mathrm{O}_{2}$ and $8 \%$ $\mathrm{H}_{2} \mathrm{O}_{2}$ (Fig. 3). Significantly lower germination of seeds was also found after sterilization by $15 \mathrm{~min} \mathrm{HgCl}_{2} \quad 12 \%$ $\mathrm{H}_{2} \mathrm{O}_{2}$ and $1 \% \mathrm{NaOCl}$ treatment when compared with the seeds sterilized by 2 or $4 \%, \mathrm{NaOCl}$ and 10,20 or $25 \mathrm{~min}$ $\mathrm{HgCl}_{2}$ treatments (Fig. 4). The infection of seeds was significantly reduced by $4 \% \mathrm{NaOCl}, 15 \mathrm{~min}, 20 \mathrm{~min}$ and

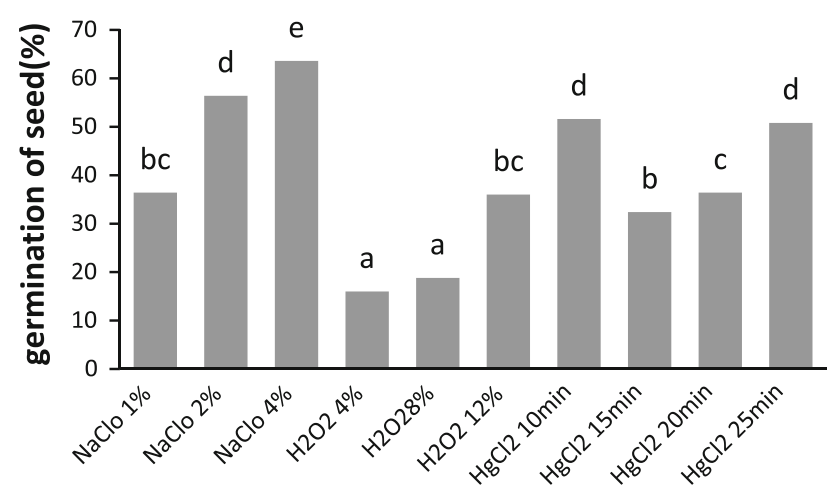

Fig. 4 Comparison of means of final germination parameter in different sterile treatments $\left(\mathrm{H}_{2} \mathrm{O}_{2} 4,8,12 \% ; \mathrm{NaOCl} 1,2,4 ; \mathrm{HgCl}_{2} 10\right.$, $15,20,25 \mathrm{~min})$
25 min $\mathrm{HgCl}_{2}$ sterilization methods (Fig. 3). These results are in agreement with the finding of other investigators (Do Rego et al. 2009; Oyebanji et al. 2009; Golle et al. 2010; Ksenija and Dragana 2005); 4 and $8 \% \mathrm{H}_{2} \mathrm{O}_{2}$ treatments were less effective than that of other treatments in sterilization of seeds.

Barnett and Varela (2004) have reported that the reduction in large populations of microorganisms on longleaf pine (Pinus palustris) with hydrogen peroxide seemed to provide the best result. Allen et al. (2004) found that Mancozeb, a protectant, and hydrogen dioxide, a disinfectant, also exhibited some efficacy in longleaf pine seed. Our results contrasted with the classical responses to sterilization by hydrogen peroxide because, it has not acted as a phytotoxic chemical for Ziziphus seeds and actually has not acted as stimulator for germination of seed. This may be because of the hard seed coat and or is it because that due to high pathogenic attack. Thus, $\mathrm{H}_{2} \mathrm{O}_{2}$ can be used as a powerful and cheap sterile solution. Our experiment reveals that $4 \% \mathrm{NaOCl}$ followed by benomyl is the best sterilization treatment for Ziziphus spina [christti].seeds, since the highest number of germination and highest number of sterilized seeds was observed after this treatment. Thus, it could represent a good method to obtain plants free of microbial contamination for seed culture. Sterilization technique using chemical solutions can be costly and potentially hazardous when used at a high concentration for large amounts of seeds (Fraedrich 1996). In addition, chemical solution is not registered as a pesticide, although some believe that it may be used legally to stratify seeds. Studies are needed to identify the concentrations of chemical solution and soaking times required to disinfect seeds efficiently. Further research is needed for the development of additional chemical and non-chemical procedures that could be used to control diseases caused by pathogens associated with Ziziphus seeds.

\section{Conclusion}

The results of our experiment showed that sterilization by $4 \% \mathrm{NaOCl}+$ benomyl is the best method to be used in surface sterilization of Ziziphus spina [christti] seeds. Seeds treated with this treatment showed the highest final germination and highest number of sterilized seeds. Fungicidal and sterile solution is an inexpensive means of disease control that can help prevent seedling losses by a variety of fungal pathogens. These treatments could increase the overall number of marketable seedlings.

Acknowledgments The authors wish to thank the Sari Agricultural Sciences and Natural Resources University for a research grant for supporting our project. We are very grateful to Mr. Mohammad 
Sayari for their assistance in the collection, generously preparation and providing acidified potato dextrose agar (APDA) for testing and also for many helpful discussions on pathogenicity mechanisms.

Open Access This article is distributed under the terms of the Creative Commons Attribution License which permits any use, distribution, and reproduction in any medium, provided the original author(s) and the source are credited.

\section{References}

Allen TW, Enebak SA, Carey WA (2004) Evaluation of fungicides for control of species of Fusarium on longleaf pine seed. Crop Prot 23:979-982

Al-Sulaiman MA, Barakat MN (2010) In vitro shoot multiplication of Ziziphus spina-christi by shoot tip culture. Afr J Biotechnol 9:850-857

Altan F, Burun B, Sahin N (2010) Fungal contaminants observed during micropropagation of Lilium candidum $\mathrm{L}$. and the effect of chemotherapeutic substances applied after sterilization. Afr J Biotechnol 9:991-995

Assareh MH, Sardabi H (2005) Macropropagation and micropropagation of Ziziphus spina-christi. Pesq Agropec Bras 5:459-465

Azam-Ali S, Bonkoungou E, Bowe C, De-Kock C, Godara A, Williams JT (2006) Fruits for the Future 2 (revised edition) Ber and other jujubes. International Centre for Underutilised Crops, Southampton

Barnett JP (1976) Sterilizing southern pine seeds with hydrogen peroxide. Tree Plant Notes 27:17-24

Barnett HL, Hunter BB (1972) Illustrated genera of imperfect fungi. Burgress Publishing Company, Minneapolis, p 241

Barnett JP, McGilvary J (2001) Reducing seed and seedling pathogens improves longleaf pine seedling production In: Moorhead DJ (ed) Proceedings of the longleaf pine container production workshop, Jan 16-18

Barnett JP, Varela S (2004) A review of chemical treatments to improve germination of longleaf pine seeds. Native Plants J $5: 18-24$

Barnett JP, Pickens B, Karrfalt R (1999) Longleaf pine seed pre sowing treatments: effects on germination and nursery establishment. Gen Tech Rep 43-46

De Moraes CF, Suzin M, Nienow AA, Grando MF, Mantovani N, Calvete EO, Donida BT (2010) In vitro artichoke seed germination. Horti Bras 28:64-69

Do Rego MM, Araujo ER, Do Rego ER, De Castro JP (2009) In vitro seed germination of Mandacaru (Cereus Jamacaru DC). Revist Caatinga 22:34-38
Dweck AC (2005) A review of Ziziphus spina-christti. http://www. personalcaremagazine.com

Farrar N, Assareh MA, Sadeghi E, Sadeghi SA (2008) Status of arthropod pests on Ziziphus spp. in South Iran. In: International Jujube Symposium Baoding, China

Fraedrich SW (1996) Seedborne diseases of southern pines and developing strategies for their control. In: National proceedings, forest and conservation nursery associations, pp 75-81

Golle DP, Reiniger LRS, Curti AR, Hanauer JG, Waldow DAG (2010) Alternative substrates and pre-germinative treatments in the in vitro germination of Pinus taeda L. Seeds Revist Arvore 34:39-48

James RL, Gilligan CJ, Dumroese RK, Wermy DL (1988) Microwave treatments to eradicate seedborne fungi on Douglas-fir seed. USDA Forest Service, Forest Pest Management, Report 88-7

Ksenija J, Dragana M (2005) Different sterilization methods for overcoming internal bacterial infection in sunflower seeds. Proc Nat Sci 109:59-64

Motamedi H, Safary A, Maleki S, Seyyednejad SM (2009) Ziziphus spina-christi, a native plant from Khuzestan, Iran, as a potential source for discovery new antimicrobial agents. Asian J Plant Sci 8:187-190

Moustafa AEA, El-Wahab RHA, Helmy MA, Batanouny KH (1998) Phenology, germination and propagation of some wild trees and shrubs in South Sinai, Egypt. Egypt J Bot 36:91-107

Murashinge T, Skoog F (1962) A revised medium for rapid growth of and bioassays with tobacco tissue cultures. Physiol Plant 15:473-497

Niedz RP, Bausher MG (2002) Control of in vitro contamination of explants from greenhouse- and field-grown trees. In Vitro Cell Dev Biol Plant 38:468-471

Oyebanji OB, Nweke O, Odebunmi O, Galadima NB, Idris MS, Nnodi UN, Afolabi AS, Ogbadu GH (2009) Simple, effective and economical explant-surface sterilization protocol for cowpea, rice and sorghum seeds. Afr J Biotechnol 20:5395-5399

Panwar P, Bhardwaj SD (2005) Hand book of practical forestry. Agrobios (India) 191

Runion GB, Bruck RI (1988) Effects of thiabendazole-DMSO treatment of longleaf pine seed contaminated with Fusarium subglutinans on germination and seedling survival. Plant Dis $72: 872-874$

Sohail M, Saied AS, Gebauer J, Buerkert A (2009) Effect of $\mathrm{NaCl}$ salinity on growth and mineral composition of Ziziphus spinachristi (L.) Willd. J Agric Rural Develop Trop Subtrop 2:107-114

Wenny DL, Dumroese RK (1987) Germination of conifer seeds surface-sterilized with bleach. Tree Plant Notes 38(3):18-22 